\title{
The Swings of Selendang: a Deconstruction Point of View of Tohari's Ronggeng Dukuh Paruk (The Dancer)
}

\author{
Suzana Maria L.A. Fajarini \\ English Letters Department, Universitas Kristen Satya Wacana \\ suzanamarialaf@gmail.com
}

\begin{abstract}
Employing different perspectives will result on different meanings of a scarf (selendang Javanese/Indonesian) in Ronggeng Dukuh Paruk (The Dancer). Known as an adornment and beautification for women in dancing costume, a scarf represents the shackle of the dancer, Srintil as the protagonist in the novel. In the different point of view, the same scarf can be a symbol of Srintil's dominance against the patriarchal system. The novel itself shows subjugation towards women done by patriarchal system. Believed to be born as a ronggeng dancer, Srintil goes through oppressions since her early adolescent. However, employing Derrida's deconstruction theory, this paper will argue that Srintil attempts very hard to achieve her liberation and to overturn the control. The swings of the scarf during the dancing denote the domination of the dancer's fated life and her self-determination as a woman. Under a strong influence of Javanese female negotiation, Srintil endeavors to liberate herself - although she is rendered to be unsuccessful - yet, there are some efforts done by her. Through some discussion the readers are supposed to observe that Srintil - who is treated unjustly by patriarchal society - manipulatively resists and fights for her freedom.
\end{abstract}

Keywords: deconstruction, patriarchal system, subjugation, resistence

\section{Introduction}

As far as patriarchal society is concerned, oppression towards women is not something new. Patriarchal ideology could be understood as an idea system that says men are in charge and women are secondary. In a broader boundary, patriarchal system is one system that tends to subjugate women and or those who are weak in which the oppressors could be men or even women as they claim to be the ones who hold power and authority.

It has been a fact that reading literary texts is less popular than other entertainment forms such as movies and television programs (Sawyer: 2000, 4). However, with its universal themes and values throughout the centuries and nations around the globe, literature persists significant as literary texts offer the readers valuable entities to learn.

On the one hand, reading literary texts may lead readers to mainly follow the author's intent which usually occur when someone reads with lower level of thinking skills. On the other hand, according to Bloom in order to develop the higher level of thinking skills, appreciation and interpretation are required (Tankersley, 2005: 148).

Ahmad Tohari's Ronggeng Dukuh Paruk is one example of a literary text which carries certain values hidden in the story line. It does not only talk about the main character's life, but also an account to the resistance toward subjugation. When the readers employ 
certain perspective in reading this text, the story is unfolded into contradiction.

This paper aims to invite readers, especially Ronggeng Dukuh Paruk's, to experience reading against the grain. That is through employing the deconstruction to see the hidden value the story carries. Thus, it opens our perspective to be aware of the subjugation happened throughout the story and to acknowledge how the protagonist, Srintil, showed her resistance toward her seemingly submissive actions.

\section{Deconstruction}

Deconstruction is one of the literary theories which is believed to permit and enhance the readers to think critically. Instead of reading the text with the mind of the author's purpose, deconstruction emphasizes interpretation with a subjective approach (from the reader's side). Furthermore, deconstruction comes in due to the fact that readers perceive things with different point of views and perspectives.

Deconstruction is described differently by different critics and thinkers. But it is believed that deconstruction is, to some extent, reaction of Ferdinand De Sauussure and Claudi Levi Strauss's concept of structuralism. Structuralism deals language as the main feature of human understanding whereas deconstruction believes that through language not only we can understand the phenomena but it also gives shape to it. As a consequence, structuralism finds the systems in the language and it construes the world accordingly but deconstruction decodes the systems and its hidden messages inherent in language.

The term deconstruction is a process done by post structuralist to 'decontruct' a text (Barry, 1995 (2017): 70). The reputation of using Derridean deconstruction is undisputable in order to enhance the critical reading skills of the readers. In order to achieve satisfaction in viewing literary texts from alternative viewpoints and perspective, deconstruction is considered to be successful as one of the most effective instruments.
Barry adds that the difference is that structuralism makes the meaning of a text definitive and to find unity of purpose within the text, deconstruction assists the readers to come up with their own interpretation that may be justified through the use of the organizing principles of language and signification and to show that actually the text is at war with itself (72).

\section{Discussion}

Reading the trilogy against the grain, the following discussion may illustrate how actually Srintil, the protagonist, attempts her liberation from being shackled by her selendang into someone who dominates the people whom readers thought to be the oppressors.

\section{Papaya and Bukak Klambu Ritual}

Hellwig in Fajarini (2011: 62) indicates three symbols in the text used by Tohari in relation to Srintil's bukak klambu ritual, one of which is the offering of papaya from Rasus to Srintil. According to Hellwig this symbol actually leads the readers to infer that later on it is Rasus who is the person to have the honor. Analyzing the symbol proposed by Helwig using deconstructive literary criticism, I associate them to Srintil's effort to achieve liberation. Further lines are quoted from Hellwig's discussion followed by my interpretation.

Srintil is deflowered three times, but only Rasus is the "fortunate one." Three indications in the text foreshadow that he is destined for this task. First, when it is made known that Srintil will be initiated as a ronggeng, everyone in the village showers her with presents. Whereas all the other boys offer her mangoes and jambu fruit, Rasus gives her a papaya, a fruit that has erotic symbolic significance. An open papaya resembles the female genitals. Moreover, on Java there is a myth that a woman who wants to please a man sexually must not eat any papaya. We can interpret this gift from Rasus as an expression of his displeasure that in the future, as a ronggeng, Srintil will have to 
serve any man sexually; he would rather have her for himself.

While Hellwig associates the papaya to female genital that refers to Srintil's femininity, in this study I propose a different opinion. Employing the setting of the trilogy is a rural area of Banyumas where Banyumasan dialect is supposed to use, the conversation would be as follows.

(1) "Srin, kiye tak gawakna gandul." [(Srintil) Here I bring you a papaya]

(2) "Srin, kiye gandul nggo kowe." [(Srintil) I have a papaya for you]

(3) "Srin, kiye ana gandul." [(Srintil) Here is a papaya (for you)]

The word gandul in Javanese has another meaning of hanging, dangling, or clustering. In my perception, the word, then, resonates more to male genitals rather than female genitals. Accordingly, my interpretation on the gift of papaya (or gandul in Banyumasan dialect) is Rasus presents himself to Srintil rather than to show his displeasure to Srintil's being a ronggeng. In my opinion, Tohari uses the metaphor of papaya to show how Rasus bestows his masculinity before Srintil. It is also supported by Rasus's statement: One time, I thought I had found a sly method for regaining her attention. His gift is presented to repossess Srintil's attention after she shows negligence towards him due to people's attention showered to her and cause Rasus to feel jealous of it. Apart from that, readers learn that Rasus cannot join the competition on mosquito netting ritual as he does not have any golden ringgit. That's why he is lowering himself in order to have Srintil for himself.

Attached to the above discussion regarding papaya, Hellwig observed the incident before the bukak klambu ritual. Hellwig notes along these lines.

Third is an incident that occurs on the afternoon before the bukak kelambu. When Srintil and Rasus meet by chance on the holy grave of their ansector, Rasus sees a mosquito on Srintil's cheek. On her request, he kills it: "I pressed Srintil's cheek. When I took my hand away, there was a small line of blood, a red spot on a white cheek." The red blood on the virginal white cheek is evocative enough, but there is also the association of the mosquito with the bukak kelambu. Rasus will be the first to open Srintil's "mosquito net".

The idea of Rasus will be the first to open Srintil's "mosquito net" is confirmed by readers later. However, the one who has the initiative is Srintil, not Rasus. Her decision to give the honor to Rasus - despite her immaturity - shows how Srintil holds her power to break the sacred ritual which is upheld by Paruk people. One chain of long established value concerning the ritual of bukak klambu is already shattered on that particular night. Should readers follow the lines in the text with the grains a quick assumption will be extracted that Srintil is weak and submissive in her immaturity. Nevertheless, reading against the grain, it is proven that Srintil is a decisive young maiden. Instead of letting other man/men to initiate her, she is consciously let Rasus to be the first to deflower her.

A character is a channel for the writer to express the writer's ideas and opinions. In those particular scenes, Srintil is rendered into the portrayal of a rebellious woman from patriarchal society which is the reverse of dominant principle in Javanese society in which men have the control. Though it seems that Srintil is depicted as the victim of life in order to show that woman is weak, reading against the grains I observe that Tohari's intention to plot Srintil's life in such a way is to show how appalling the patriarchal system is.

\section{The Term Mewisuda}

Fajarini (2011: 95) writes that regarding the bukak klambu ritual which symbolizes Srintil's initiation to undergo losing her purity, Tohari, captivatingly, use the word mewisuda instead of memerawani (from the stem word perawan meanings maiden) or menggagahi (from the stem word gagah meanings being a mannish man over a woman, euphemism of English phrase to 
rape). The following lines will show how the word mewisuda is brought into play.

Siapa yang akan menyalahkan Kartareja bila dukun ronggeng itu merasa telah menang secara gemilang. Siapa pula yang akan menyalahkan Dower bila dia kelak berteriak-teriak bahwa dirinyalah yang telah mewisuda ronggeng Srintil. Sesuatu telah terjadi di belakang rumah Kartareja sebelum Dower menyingkapkan kelambu yang mengurung Srintil. Hanya aku dan ronggeng itu yang mengetahui segalanya. (RDP, 1995: 75)

[Who could blame Kartareja for feeling that he had done so well? And who could blame Dower for later claiming that he was the one who deflowered Srintil? But something had happened behind Kartareja's house before Dower opened the mosquito netting that encircled Srintil. Only Srntil and I knew what it was.] (TD, 2003: 77)

According to Kamus Besar Bahasa Indonesia, the word mewisuda - from the stem word wisuda - has the meaning to inaugurate officially with a formal ceremony either in academic sphere or in career promotion'. Therefore, when I read it for the first time, I personally thought that the word does not fit the paragraph as it sounds too intellectual and ornamental regarding who Srintil is and what she is experiencing. What I mean by intellectual and ornamental is the word is not a common word I usually find in newspapers regarding the idea of 'to deflower', such as meniduri (from tidur meanings to sleep on), menodai (from nodameanings to stain), or memerawani (from perawan - meanings to deflower a maiden). Therefore, I have thought the word is ornamental too, it does not fit the description of Paruk people as humble, simple, and ignorant people. The word then becomes artificial in the whole narrative.

Nevertheless, reading against the grain I perceive irony and cynicism expressed by Tohari by using the word which I considered too intellectual and artificial. I have two clarifications for the use of the word mewisuda. The first clarification is the mosquito net ritual is described as an inauguration of Srintil from a maiden to be a ronggeng dancer, from being an innocent girl to a woman. Referring to Kamus Besar Bahasa Indonesia, then, despite how sarcastic the diction mewisuda is, the text narrates the fact of Srintil's initiation. The second reason is the word wisuda - in Javanese - can be a deformation of a word pun wis (w)uda which means is already naked. Thus, mewisuda can be a cartoon of someone has unclothed someone else, say in the context discussed it is narrated that Dower believes he has unclothed Srintil.

Further searching of the the word wuda (English: to be naked), it originally comes from Arabic word hudan (English: to be naked) which then in Javanese is pronounced as wuda. Considering that Tohari has grown up in Islamic ortodox family, I supposed he learns Arabic to some extent. He knows the meanings of the word hudan and wuda and how close the word wuda is to be twisted to Indonesian word mewisuda. Whether Tohari choose the diction mewisuda intentionally or unintentionally from other terminology, my very argument for it is the text has completely been written, detached from the author, and the text itself gives the readers freedom to interpret it.

Literally, mewisuda has a positive attitude. I learn from the context that the word is used to criticize the patriarchy. Men who adore virginity think they elevate the maiden's status by mewisuda, on the contrary they actually destroy the girl's purity through deflowering her. Hence, the word mewisuda in the context is a decline of the condition.

\section{The Shackle of Indang}

To the people of Dukuh Paruk, having an indang possessed dancer is very special. Their belief and old tradition do not consider a ronggeng dancer as a vulgar, degrading, or improper woman. In fact, a ronggeng for Paruk people is their tradition and without ronggeng they would lose their prestige $(T D$, 169). Using Bandel's terms, the people of this 
small poor hamlet live in their own 'world' without realizing that their life practice and value are considered immoral by the outsiders (Bandel, 2006: 137). Tohari's describes the 'oddity' related to Paruk people's moral values in a natural way, wrapped in being illiterate and isolated that readers can accept the explanation as an ordinary cause-effect.

Being portrayed as primordial isolated community, the people of Dukuh Paruk strongly believe that Srintil's sudden ability to dance is a result of the indang's infiltration [the dancer spirit that possesses Srintil]. The Javanese philosophy of kebetulan coincidence - which is closely related to luck works for Srintil's life. For its believers, a luck is really something they neither can achieve nor avoid. A luck comes to a particular person from the supreme being or power beyond human capacity, as in Srintil's case when she is possessed by the indang. Thus, coincidences become the way how Srintil from being nobody - turns out to be a famous ronggeng dancer later on. Coincidences that lead Srintil to be designated as a ronggeng can't be explained unless as part of the indang-related mysticism believed by the people of Dukuh Paruk.

Back to Srintil's emergence as a village dancer, in my understanding, Tohari shows the eleven years of vacuum and the sudden appearance of Srintil as a ronggeng to emphasis how significant and important Srintil is in the trilogy as a dancer. She plays an important role, becomes the central figure of Dukuh Paruk and the trilogy, give comfort and pride to Paruk people, and moves the narrative itself. Just like a mother longs for a baby, and after more than a decade the baby is born, so is Srintil to Dukuh Paruk. She fulfills the thirst of the people, she completes the missing piece of puzzle they used to have. Her aura as a new ronggeng dancer is a kind of consolation for the people of Dukuh Paruk. Therefore, the people of Dukuh Paruk adore Srintil and feel blessed that finally they have this young girl to give identity to this small village.

With their ignorance and superstitious values as it is portrayed in the trilogy, people of Dukuh Paruk cannot rationally understand Srintil's capability and talent that appear in a sudden. They simply understood as 'spirit sent by their ancestor' to reside in Srintil's body.

Despite Srintil's significance and existence is adored and appreciated by Paruk people, and at the same time she is exploited by the Kartarejas, Srintil is not accepted by the outsiders, especially by women of higher status. They consider her as a rival. Srintil who is considered a mascot and heroin by Paruk people especially by the women - is only considered an object of pleasure and desire for men off this impoverished backward village. To these men, Srintil is an object who 'can be paid and get pleasure from', a sexually charged dancer. However, at the same time Srintil actually overpowers these men and entraps them in her intimate magnetism.

Applying deconstruction literary theory, it can be said that Srintil, an enchanting young woman who is adored and loved by the villagers of her birth place, dominates men and women off her tiny village. Men, especially the local bureaucrats, are infatuated with her. Their wives, conversely, in their envy, bitterness, and antipathy consider her as a rival. The women from higher status consider Srintil as an intimidator. Srintil, the young woman shackled by the indang, swings her selendang of life from being dominated by her fate, by the Kartarejas to someone possessing a power and subjugates men under her charisma.

Nevertheless, after being imprisoned, Srintil attempts to unchain herself from her destiny as a ronggeng dancer. She rejects men's invitations to have love adventures. She also gets rid of Nyi Kartareja's domination. Her refusals to serve men's passions indicate that she does not let herself be regarded as 'a gulp of water for every man's thirst. The refusals also prove that she decides to manage her life herself. 


\section{Conclusion}

A person is aware there are problems in her/his life when s/he comprehends that something is wrong. Readers learn that being constrained in the male-dominated society Srintil is aware the troubles she has, and negotiates her liberation. Srintil is not passive and submissive. The proofs in discussion indicate her efforts. Balkin identified that deconstruction shows that texts are overflowing with multiple and often conflicting meanings, not a single meaning as they are written. Deconstructive arguments do not necessarily destroy basic concept, rather, they tend to show that conceptual oppositions can be reinterpreted as a form of nested opposition (Balkin, 1990: 40).

Excavating the problems experienced by Srintil, readers will easily conclude that she is shackled by her misfortune in spite of her endeavors to free herself from her destitution. However, scoop out the dirt and scrutinize her struggles, the discussion in this paper shows and confirms how Srintil manipulatively fights and solves the problems. Employing Derrida's deconstruction, Srintil's endeavors can be said as movements of her control over the patriarchal society.

\section{References}

Balkin, J.M. "Nested Oppositions," Faculty Schoolarship Series. Paper 281. 1990.

Bandel, Katrin. Sastra, Perempuan, Seks. Yogyakarta: Jalasutra, 2006. Print.

Barry, Peter. Beginning Theory. Manchester: Manchester University Press, 1995 (2017). Print.

Fajarini, S.M. Luki Astuti. "The Swaying of Oppression and Liberation through Srintil's Selendang in Tohari Trilogy Ronggeng Dukuh Paruk and The Dancer." Graduate Thesis. Yogyakarta: Sanata Dharma University, 2011. Print.
Hellwig, Tineke. In The Shadow of Change: Images of Women in Indonesia Literature. Barkeley: California University Press, 1994. Print.

Jao, L., Limpingco, D. \& Tiangco, G. Psychology of Learning. Quezon City: Ken Incorporated, 1998. Print.

Sawyer, W. Growing up with Literature. Albany, NY: Delmar, 2000. Print.

Tankersley, Karen. Literacy Strategies. USA: ASCD, 2005. PDF.

Tohari, Ahmad. Ronggeng Dukuh Paruk (under one cover). Fifth Edition. Jakarta: PT Gramedia Pustaka Utama, 1995. Print.

The Dancer. Third edition. Jakarta: PT Gramedia Pustaka Utama, 2003. Print.

Mahachulalongkornrajavidyalaya University, 2010.

Pintong, P. Phayas: Traditional Isan Verse [in Thai]. Ubonrachatani: Siritham Publishing, 1985.

Suvannasri, P. An Analysis of Phaya-Isan: Values, Existence and Transmission. Chulalongkorn University, 2004.

Tangkawee, S. Knowledge and skill in language [in Thai]. Bangkok: Odeon Store, 1985. 